\title{
Epipelagic mesozooplankton distribution and abundance over the Mascarene Plateau and Basin, south-western Indian Ocean
}

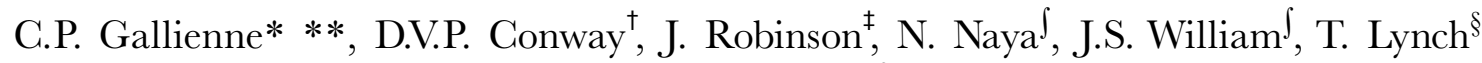 \\ and S. Meunier ${ }^{\S}$
}

*Plymouth Marine Laboratory, Prospect Place, Plymouth, PL1 3DH. ${ }^{\dagger}$ Marine Biological Association, The Laboratory, Citadel Hill,

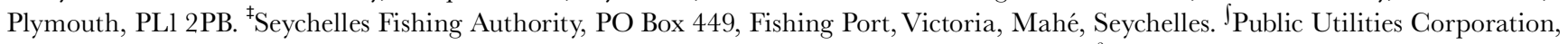
Water and Sewage Division, Laboratory Section, New Port, Victoria, Mahé, Seychelles. ${ }^{\S}$ Shoals Rodrigues, Pointe Monier, Rodrigues Island, Mauritius. ${ }^{* *}$ Corresponding author, e-mail: cpg@pml.ac.uk

The crescent shaped Mascarene Plateau (south-western Indian Ocean), some $2200 \mathrm{~km}$ in length, forms a partial barrier to the (predominantly westward) flow of the South Equatorial Current. Shallow areas of the Mascarene Plateau effectively form a large shelf sea without an associated coastline. Zooplankton sampling transects were made across the plateau and also the basin to the west, to investigate the role the partial interruption of flow has on zooplankton biomass and community structure over the region. Biomass data from optical plankton counter (OPG) analysis, and variability in community structure from taxonomic analysis, appear to indicate that the obstruction by the plateau causes upwelling, nutrient enrichment and enhanced chlorophyll and secondary production levels downstream.

The Mascarene Basin is clearly distinguishable from the ridge itself, and from the waters to the south and north, both in terms of size-distributed zooplankton biomass and community structure. Satellite remote sensing data, particularly remotely-sensed ocean colour imagery and the sea surface height anomaly (SSHA), indicate support for this effect. A correlation was found between OPC biovolume and SSHA and sea surface temperature (SST), which may indicate the physical processes driving mesozooplankton variability in this area. Biomass values away from the influence of the ridge averaged $24 \mathrm{mg} \mathrm{m}^{-3}$, but downstream of the ridge biomass averaged $263 \mathrm{mg} \mathrm{m}^{-3}$. Copepods comprised $60 \%$ of the mean total organisms. Calanoid copepod numbers varied considerably between regions, being lowest away from the influence of the plateau, where higher numbers of the cyclopoid copepods Oithona spp., Corycaeus spp. and Oncaea spp., and the harpacticoid Microsetella spp. were found.

\section{INTRODUCTION}

The Mascarene Plateau, in the south-western Indian Ocean, lies atop an aseismic ridge, formed from volcanic activity of the Reunion hot spot between 20 and 40 million years ago (Bonneville et al., 1997). The ridge is some $2200 \mathrm{~km}$ in length, running from the Seychelles Bank at $4^{\circ} \mathrm{S}$ to the island of Mauritius at $20^{\circ} \mathrm{S}$, and is oriented roughly north-south in a crescent shape (Figure 1). The Seychelles Bank is not of volcanic origin, but granitic, and probably a continental crustal remnant of the break-up of Gondwanaland, as the African and Asian continents separated (Gabriel et al., 2000). The islands, banks and shoals of the ridge form a barrier, continuous at depth, but permeable above $\sim 1500 \mathrm{~m}$. The ridge shallows to $20 \mathrm{~m}$ in many areas of the banks at the north of the plateau, and in places the $200 \mathrm{~m}$ isobath is more than $250 \mathrm{~km}$ wide. The banks and shoals of the Mascarene Plateau effectively form a large shelf sea without an associated coastline.

Although many parts of the Indian Ocean have been extensively studied, the few surveys conducted in the south-western Indian Ocean have characterized the Mascarene Plateau and Basin only superficially, or not at all. See Rao (1998) and Piontkowski et al. (1995) for summaries of the International Indian Ocean Expedition (IIOE, 1960-1965) and Russian studies in this region. The Mascarene area thus remains a unique and almost completely undescribed large marine ecosystem.

Although the most northerly part of the study area is under the influence of the north-east monsoon from December to February, during the remainder of the year, and certainly during the period of our study, the whole area is under the influence of the South-east Trades and the South Equatorial Current. Studies of physical data gathered during the IIOE and later, have indicated that the Mascarene Ridge affects the predominantly westward zonal flow of the South Equatorial Current, causing divergence on the leeward side, especially during winter. This would result in upwelling and consequent nutrient enrichment (Ragoonaden et al., 1987; Sarma et al., 1990), which could lead to a higher zooplankton biomass in the areas downstream of the ridge, in response to enhanced primary production. The effects might also manifest themselves as variability in community structure (Raymont, 1983).

The Shoals of Capricorn Programme (Burnett et al., 2001) of the Royal Geographical Society (with the Institute of British Geographers) and the Royal Society, conducted marine research around the Mascarene Plateau between 1998 and 2001 from bases in the 


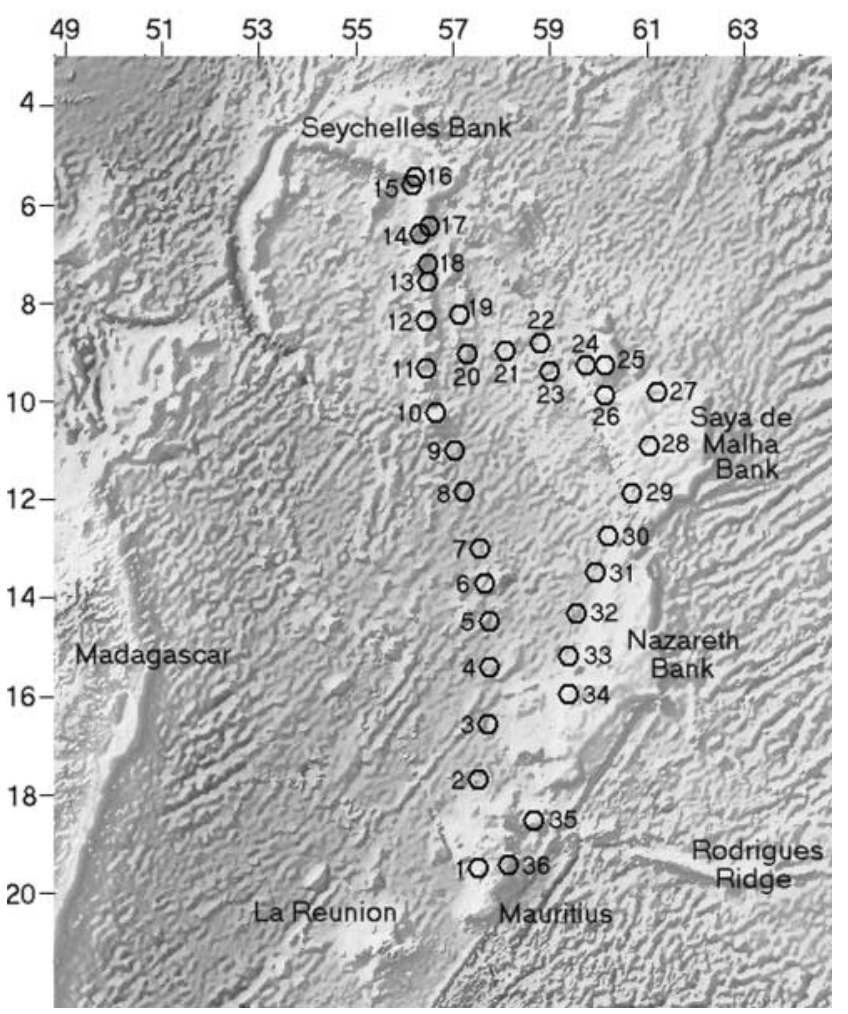

Figure 1. Sea floor topography of the south-western Indian Ocean (Sandwell \& Smith, 1997). Sampling Stations 1-36 indicated. Longitude in degrees east, latitude in degrees south.

Seychelles and Mauritius. As a part of this programme, the $20 \mathrm{~m}$ sailing research vessel (SRV) 'Zuza' was used to carry out a biological and hydrographic survey of the Mascarene Plateau and Basin between Seychelles and Mauritius. This paper reports the findings of the zooplankton survey, which formed a part of this research cruise. The purpose of the survey was to investigate to what extent enhancement of secondary production and variability in community structure, exists in the waters around the Mascarene Plateau.

\section{MATERIALS AND METHODS}

The SRV 'Zuza' departed Port Louis, Mauritius on 27 April 2001 for the north-bound leg across the Mascarene Basin to the Seychelles, where it arrived on 4 May. The cruise track followed a more or less direct route across the Mascarene Basin, downstream of the ridge system and wholly in deep, oceanic water (Figure 1). All stations were in 2000-5000 m of water, except the first ( $\sim 600 \mathrm{~m})$. The 'Zuza' left the Seychelles on 7 May for the south-bound leg, which followed a track much closer to and sometimes on the ridge, with depths of 30-3600 m. The cruise finished in Mauritius on 19 May 2001.

Net samples for mesozooplankton were taken three times a day along the transects, at intervals of approximately 50 n.m. Sampling was carried out at 15 stations on the north-bound transect and 21 on the south-bound transect, a total of 36 samples. The zooplankton net used was a conical, $0.4 \mathrm{~m}$ diameter hand net of $125-\mu \mathrm{m}$ mesh aperture, fitted with a General Oceanics flowmeter and an $11 \mathrm{~kg}$ weight. The net was lowered from the aft diving platform on $100 \mathrm{~m}$ of nylon line, then hauled back to the surface. Unavoidable drift on station whilst hove to (typically $1 \mathrm{kn}$ downwind) meant that the depth sampled, obtained from depth sensor readings, was typically 20-50 m. Net samples therefore represent only the surface mixed layer. On net recovery, the sample was immediately washed out of the cod end on to a sieve using filtered seawater, prior to preservation in $4 \%$ buffered formaldehyde solution.

Upon reaching the Seychelles, the samples from the first leg were sub-sampled and processed through an optical plankton counter (OPC; Herman, 1992) at the Shoals of Capricorn base. The mesozooplankton samples from the second leg were similarly sub-sampled and processed, using identical equipment, at the Shoals of Capricorn base on Rodrigues Island, Mauritius.

The OPC produces a reliable and robust estimate of mesozooplankton numbers and size, in the size range $250 \mu \mathrm{m}-16 \mathrm{~mm}$ equivalent spherical diameter (ESD), yielding a size distribution which can be converted into biomass (Gallienne \& Robins, 1998; Gallienne \& Robins, 2001; Gallienne et al., 2001). Mesozooplankton biomass $\left(\mathrm{mg} \mathrm{m}^{-3}\right)$ data were derived from OPC biovolume $\left(\mathrm{ml} \mathrm{m}^{-3}\right)$, assuming a specific gravity for mesozooplankton of 1. Biovolume is calculated as follows. Particle crosssectional area (CSA) is calculated from OPG digital size (DS) as: $\mathrm{CSA}=0.0102 * \mathrm{DS}$. Particle volume is calculated assuming an ellipsoidal model with a length-to-width ratio of 3 .

Mesozooplankton sub-samples were adjusted to always give a minimum OPC count of 2000 individuals. Using a value of $1.33 *$ mesh size for body width, and a 3:1 length to width ratio, the body length of the smallest organism quantitatively sampled may be taken to be $500 \mu \mathrm{m}$, or Author: approximately $250 \mu \mathrm{m}$ ESD (Gallienne \& Robins, 2001). ${ }_{\text {does }}^{\text {what }}$ The choice of net mesh size was therefore well matched to the size range discrimination of the OPC.

Taxonomic analysis of the zooplankton samples from for? both legs was subsequently carried out at the Shoals of Capricorn bases and at the Marine Biological Association Laboratory in Plymouth, UK. Analysis was to genera if possible, but only to broader assemblages with some specialist groups, immature and damaged specimens. The second sample taken on the north-bound leg was badly preserved after the OPC analysis and was discarded, so a total of 35 samples were analysed taxonomically.

Physical and chlorophyll measurements were not taken during the cruise. However, in order to obtain some estimate of the physical and biotic environment, remotelysensed, along-track values for sea surface temperature (SST), chlorophyll- $a$ concentration and sea surface height anomaly (SSHA) for the sampling period, were extracted from Advanced Very High Resolution Radiometer (AVHRR), Sea-viewing Wide Field-of-view Sensor (SeaWiFS) and TOPography Experiment for Ocean Circulation (TOPEX/Poseidon) altimeter data respectively.

\section{RESULTS}

\section{Distribution of mesozooplankton biomass}

Mesozooplankton biomass for all net samples taken along the north- and south-bound transects are shown in Figure 2. The SSHA is also shown, derived from 

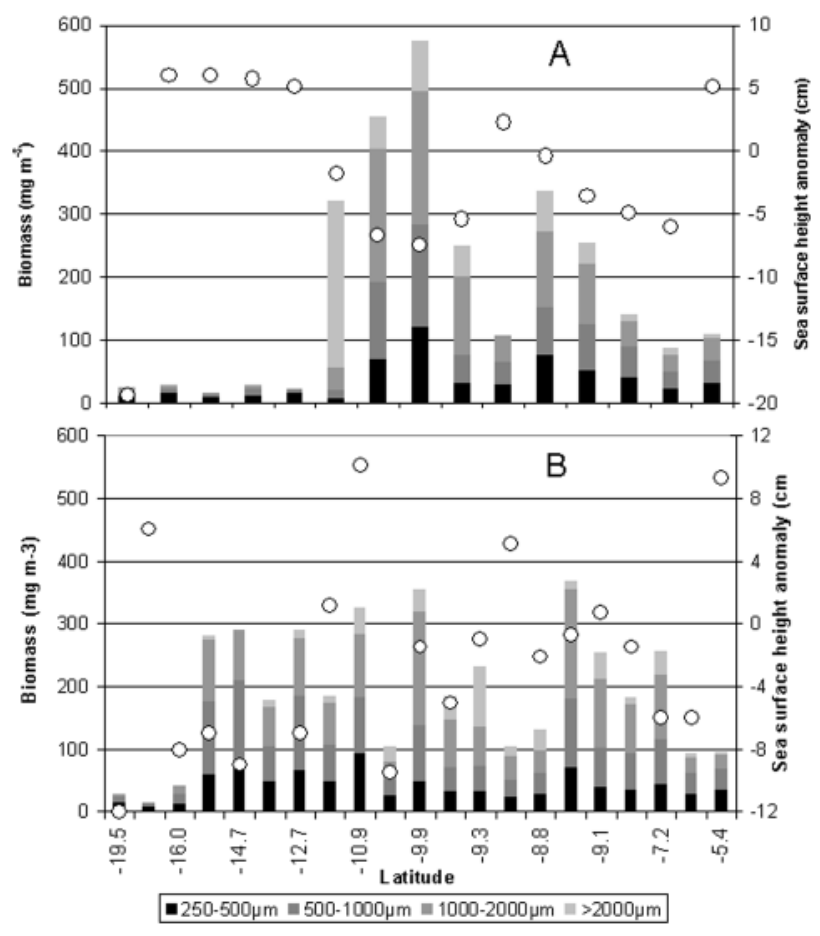

Figure 2. Total size-fractionated optical plankton counter mesozooplankton biomass on the (A) north-bound leg and (B) south-bound legs. Key: size fractions, equivalent spherical diameter. The SSHA is also shown (circular symbol), derived from TOPEX/Poseidon altimeter data for the period of the survey (10-d averages).

TOPEX/Poseidon altimeter data for the period of the survey (10-d averages).

In the north-bound data set (Figure 2A), from Mauritius $\left(19.5^{\circ} \mathrm{S}\right)$ up to $14^{\circ} \mathrm{S}$, biomass values average $24 \mathrm{mg} \mathrm{m}^{-3}$ (minimum 15, maximum $29 \mathrm{mg} \mathrm{m}^{-3}$ ), typical for sub-tropical, oligotrophic waters (Raymont, 1983; Gallienne \& Robins, 1998). From this point on, biomass increased greatly, averaging $263 \mathrm{mg} \mathrm{m}^{-3}$ (minimum 87, maximum $575 \mathrm{mg} \mathrm{m}^{-3}$ ), with two peaks around $11.8-13.8^{\circ} \mathrm{S}$, and $7.6-9.3^{\circ} \mathrm{S}$. There is a negative correlation between SSHA and mesozooplankton biomass, with a significant minimum in SSHA coincident with the maximum biomass. This relationship breaks down at either end of the transect, but in the area downstream of the major banks and gaps (between 8 and $18^{\circ} \mathrm{S}$ ), the relationship is highly significant. The relationship is expressed as $\ln (\mathrm{OPC}$ biovolume $)=-0.24 * \mathrm{SSHA}+217.57, \quad r^{2}=0.87$, $\mathrm{F}=60.05, P<0.001$ for the 11 samples in this part of the transect (Table 1). There is also a significant, though weaker positive correlation between $\ln$ (OPC biovolume) and SST between these latitudes, although this appears to reflect a general increase in SST south to north (biomass is higher in the northern than in the southern part of the transect). No significant correlation exists between $\ln$ (OPG biovolume) and chlorophyll concentration in either the restricted latitudinal range, or for the whole transect.

Figure 2B shows the data for the south-bound leg, which represents net hauls taken very much closer to, or on the Mascarene Plateau (see Figure 1), and may therefore be considered shelf sea samples. Mean biomass for this leg is
Table 1. Regression statistics for In (optical plankton counter biovolume) against sea surface height anomaly (SSHA), sea surface temperature (SST) and chlorophyll concentration (CHL). Statistics for SSHA and SST in the north-bound leg are for the 11 samples between 8 and $18^{\circ} S$ and in the southbound leg for the 18 samples between 5 and $10^{\circ} \mathrm{S}$.

\begin{tabular}{lccccc}
\hline & Coefficient & $r^{2}$ & $\mathrm{~N}$ & $\mathrm{~F}$ & $P$ \\
\hline North-bound & & & & & \\
SSHA & -0.24 & 0.87 & 11 & 60.05 & $<0.001$ \\
SST & 1.66 & 0.47 & 11 & 8.10 & $<0.05$ \\
CHL & 12.32 & 0.11 & 15 & 1.66 & n.s. \\
& & & & & \\
South-bound & & & & & \\
SSHA & -0.005 & 0.004 & 18 & 0.072 & n.s. \\
SST & -0.58 & 0.26 & 18 & 5.71 & $<0.05$ \\
CHL & 2.83 & 0.08 & 18 & 1.57 & n.s. \\
\hline
\end{tabular}

$208 \mathrm{mg} \mathrm{m}^{-3}$ (minimum 42, maximum $370 \mathrm{mg} \mathrm{m}^{-3}$ ). No significant correlation exists between OPC biovolume and either SSHA or chlorophyll (Table 1), although there is a significant but very weak correlation with SST. This was true for all 21 samples, and for any sub-set thereof. The data for the south-bound leg in Table 1 are for 18 stations between 5 and $18^{\circ} \mathrm{S}$ for which the regression fit was optimal.

\section{Species distribution}

In order to examine the hypothesis that flow across and around the ridge results in upwelling and leads to a higher zooplankton biomass in the areas downstream of the ridge, we used multivariate statistical analysis of the species distribution of zooplankton. The study area was divided into three regions, based upon geographic location, water depth, satellite imagery of chlorophyll biomass and an assessment of the variability of size-distributed biomass from the data presented in Figure 2. Each station was allocated to one of three zoogeographic regions based upon these factors. The first region is named oligotrophic (OL), the low-biomass areas south and west of the Mascarene Plateau and south of the Seychelles Bank, outside of the area of enhanced chlorophyll indicated by SeaWiFS imagery to the west of the Mascarene Plateau. Second is this area of enhanced chlorophyll downstream of the ridge, hypothesized to be subject to nutrient enrichment due to physical processes, as the South Equatorial Current meets the obstruction of the Mascarene Plateau, and named north-bound upwelling (NU). The last region includes all stations on or near the shallow banks of the Mascarene Plateau (MP). The allocation of stations to each of these three regions is detailed in Table 2.

It is valuable to present the species/group analysis data from the 35 zooplankton samples in some detail, as a record for the region. The data are too comprehensive to give in full, so are described briefly here and summarized in Table 3, separately for the three zoogeographical regions determined (Table 2).

When the zooplankton analysis data are considered, numbers of organisms found in each sample mirror the biomass data. The species/group range varies between the three regions, but the total species diversity is similar. The 
Table 2. Groups for discriminant analysis of taxonomic data.

\begin{tabular}{lccccc}
\hline Station & Group & Station & Group & Station & Group \\
\hline 1 & OL & 13 & NU & 25 & MP \\
2 & OL & 14 & OL & 26 & MP \\
3 & OL & 15 & OL & 27 & MP \\
4 & OL & 16 & OL & 28 & MP \\
5 & OL & 17 & OL & 29 & MP \\
6 & NU & 18 & MP & 30 & MP \\
7 & NU & 19 & MP & 31 & MP \\
8 & NU & 20 & MP & 32 & MP \\
9 & NU & 21 & MP & 33 & MP \\
10 & NU & 22 & MP & 34 & OL \\
11 & NU & 23 & MP & 35 & OL \\
12 & NU & 24 & MP & 36 & OL \\
\hline
\end{tabular}

MP, Mascarene Plateau; NU, north-bound upwelling; OL, oligotrophic.

11 samples from the OL region had a mean number of $827 \pm 136.3$ organisms $\mathrm{m}^{3}$ from 101 species/groups, the 8 samples from the NU region a mean number of $3162 \pm 485.2$ organisms $\mathrm{m}^{3}$ from 98 species/groups and the 16 samples from the MP region a mean number of $2524 \pm 323.0$ organisms $\mathrm{m}^{3}$ from 94 species/groups.

Copepods, typically the most numerous component of zooplankton samples, comprised similar proportions, $57 \%, 62 \%$ and $59 \%$, of the mean total organisms $\mathrm{m}^{3}$ in the samples from the OL, NU and MP regions respectively. However, the proportion of the copepods which were calanoid copepods varied considerably between the same three regions, at $23 \%, 46 \%$ and $35 \%$. These differences were due to the presence of higher numbers of the cyclopoid copepods Oithona spp., Corycaeus spp. and Oncaea spp., and the harpacticoid Microsetella spp. in the $\mathrm{OL}$ and MP regions.

There were 49, 51 and 45 species/groups of copepods in the OL, NU and MP regions respectively, so slightly greatest diversity was found in the oligotrophic and upwelling regions. Certain copepods such as Undeuchaeta spp., only found in the NU region, could be an indication of upwelling, while Temora discaudata, which is a common shallow water species, was most abundant in the MP region.

\section{Discrimination of zoogeographic regions}

At the mesoscale, community variability is apparent as shifts in dominance between the most common species present (Mackas et al., 1985). In order to examine community variability between regions around the Mascarene Plateau, statistical analysis of the taxonomic data was undertaken.

Prior to the statistical analysis, the data for all of the species or groups obtained from taxonomic analysis were reduced by combination to major groups, and all such groups which were present at less than nine of the 36 stations were excluded. The data for the 27 major taxonomic groups which remained were fourth-root transformed to stabilize variance, to bring the distribution of counts closer to normality and to remove dependence of the variance on the mean (Sokal \& Rohlf, 1995). The transformed data were then examined for groupings and patterns, using single-linkage hierarchical clustering on the Euclidean distance matrix derived from these data (SYSTAT; Wilkinson et al., 1996).

No meaningful groups were apparent from this clustering, apart from one containing Stations 1-6 and 34-36. The remaining stations were sequentially added to this group, with no particular pattern emerging. This analysis was therefore not capable of discriminating any significant zoogeographic zonation in the data.

A more powerful statistical tool was then applied to the data, stepwise linear discriminant function analysis (SYSTAT; Wilkinson et al., 1996). The purpose of this analysis is to find linear combinations of variables that maximize differences among $k$ predefined groups. The question posed is then: 'Are there significant differences among the $k$ groups?' This method has the advantage that the groups are specified beforehand (assuming some knowledge to enable this specification).

The analysis was performed on the double square root transformed data for the 27 major taxonomic groups used in the cluster analysis, separated into three groups (the regions of Table 2). Of the 27 major groups, 16 were found to be significant in the discriminant analysis. The analysis resulted in just two factors (linear weighted combinations of the 16 data values for each station). These weighting coefficients (standardized by within-species variance) for each of the two factors are listed in Table 4.

It can be seen from Table 4, that the most significant taxa in the determination of grouping factor 1 are the copepods Oncaea spp., Microsetella spp., echinoderm larvae, polychaete larvae, and the foraminiferan Globigerina spp. For factor 2 the significant groups are gastropod larvae, Chaetognatha, Acrocalanus spp., Microsetella spp., Corycaeus spp. and polychaete larvae. The first factor accounted for $51 \%$ of the total dispersion of the data, and all the remaining dispersion was accounted for by factor 2. This was significant at better than $0.1 \%$ (approximate $\mathrm{F}=9.4 ; \mathrm{df}=32,34 ; P<0.0001$ ); the critical value for $\mathrm{F}$ for this analysis is $\geqslant 3.01$ at $P<0.001$. Table $5 \mathrm{~A}$ shows $100 \%$ success at classification for each station.

It should be noted that the grouping in Table $5 \mathrm{~A}$ is determined from observations within that group, so that there is a bias in favour of allocating individuals to the group they really come from. The 'jackknife classification' of Table 5B overcomes this problem by allocating individuals to the closest group without using that individual to help determine that group, thereby avoiding bias (Manly, 1994). The classification fit is still 97\%, indicating that the classification is reliable.

The factor scores for each of the 16 major groups for each station were then used to display the grouping described by the discriminant analysis, using the same hierarchical clustering method as before. The three groups were clearly separated. As suggested by Table 4, this analysis shows that a single, simple linear weighted combination of the taxonomic data yields a classification scheme clearly separating the data between the three regions chosen. Field et al. (1982) point out that clustering dendrograms have certain disadvantages in displaying the relationships between samples, and it is therefore advisable to employ an additional (complementary) method. If the two methods agree, the grouping can be accepted as real. Figure 3 shows the data from the discriminant function 
Table 3. Zooplankton species/group list and mean numbers $\mathrm{m}^{3}$ from samples from each of the three zoogeographic regions.

\begin{tabular}{|c|c|c|c|c|c|c|c|c|c|c|c|c|c|c|c|}
\hline Species/group & $\mathrm{OL}$ & $\mathrm{NU}$ & MP & Species/group & OL & NU & MP & Species/group & $\mathrm{OL}$ & $\mathrm{NU}$ & MP & Species/group & $\mathrm{OL}$ & $\mathrm{NU}$ & MP \\
\hline COPEPODA & & & & Subeucalanus subcrassus & 0.4 & 0.1 & 0.4 & ISOPODA & & & & Polyclad larvae & $\mathrm{P}$ & - & 2.1 \\
\hline Lucicutia flavicornis & 0.8 & 10.2 & 0.9 & Aetideus giesbrechti & - & $\mathrm{P}$ & - & Isopod sp. & - & - & $\mathrm{P}$ & NEMERTINEA & & & \\
\hline Pleuromamma abdominalis & 0.5 & $\mathrm{P}$ & - & Euchirella pulchra & $\mathrm{P}$ & 1.0 & - & Isopod microniscus stage & 0.4 & & 2.7 & Pilidium larvae & - & - & 6.4 \\
\hline Pleuromamma gracilis & - & 0.1 & - & Undeuchaeta intermedia & - & $\mathrm{P}$ & - & EUPHAUSIACEA & & & & PHORONIDA & & & \\
\hline Pleuromamma indica & $\mathrm{P}$ & 0.1 & - & Undeuchaeta plumosa & - & $\mathrm{P}$ & - & Euphausiid eggs & - & 3.4 & 7.3 & Phoronid larvae & 0.2 & - & - \\
\hline Pleuromamma piseki & 0.3 & - & 0.9 & Clausocalanus spp. & 17.8 & 81.6 & 53.7 & Euphausiid nauplii & 0.5 & 3.4 & 2.5 & ECTOPROCTA & & & \\
\hline Pleuromamma xiphias & $\mathrm{P}$ & - & - & Euchaeta indica & - & 0.1 & $\mathrm{P}$ & Euphausiid calyptopis/furcilia & 1.1 & 1.9 & 7.3 & Cyphonautes larvae & 3.0 & 15.1 & 5.1 \\
\hline Acartia danae & 1.3 & 8.2 & 1.0 & Euchaeta rimana & - & 0.1 & 1.9 & Euphausiids early PL & - & 0.1 & 0.1 & EGHINODERMATA & & & \\
\hline Acartia negligens & 6.0 & 23.5 & 24.8 & Phaenna spinifera & - & $\mathrm{P}$ & - & Euphausia diomedia & $\mathrm{P}$ & $\mathrm{P}$ & $\mathrm{P}$ & Echinoderm larvae & 11.1 & 1.7 & 17.2 \\
\hline Candacia aethiopica & $\mathrm{P}$ & 0.1 & $\mathrm{P}$ & Scolecithrix bradyi & - & 1.0 & - & Pseudeuphausia latifrons & - & - & $\mathrm{P}$ & GHAETOGNATHA & & & \\
\hline Candacia bispinosa & $\mathrm{P}$ & - & - & Scolecithrix danae & 0.1 & 9.6 & 0.1 & Euphausia sp. & $\mathrm{P}$ & - & - & Chaetognath spp. & 17.1 & 81.7 & 73.3 \\
\hline Candacia catula & 0.2 & - & 1.6 & Calanoid copepods imm. & 192.2 & 922.2 & 592.2 & Stylocheiron carinatum & $\mathrm{P}$ & $\mathrm{P}$ & - & MOLLUSGA & & & \\
\hline Candacia curta & - & 0.1 & - & Oithona spp. & 97.9 & 342.1 & 346.4 & DECAPODA & & & & Prosobranch larvae & 6.1 & 15.9 & 55.0 \\
\hline Candacia pachydactyla & - & 0.1 & $\mathrm{P}$ & Clytemnestra sp. & 0.2 & - & - & Lucifer spp. & 0.3 & 4.4 & 2.2 & Echinospira larvae & - & - & $\mathrm{P}$ \\
\hline Candacia truncata & $\mathrm{P}$ & 0.6 & $\mathrm{P}$ & Euterpina acutifrons & 1.4 & 10.9 & 2.1 & Sergestid larvae & $\mathrm{P}$ & $\mathrm{P}$ & 0.8 & Gymnosome sp. & - & $\mathrm{P}$ & - \\
\hline Centropages elongatus & - & 0.8 & 0.8 & Macrosetella gracilis & 0.9 & 0.1 & 1.5 & Phyllosoma larvae & $\mathrm{P}$ & - & - & Desmopterus papilio & $\mathrm{P}$ & - & - \\
\hline Centropages furcatus & 2.0 & 9.4 & 4.9 & Microsetella norvegica & 10.7 & 67.5 & 41.7 & Decapod larvae & 0.8 & 0.8 & 4.9 & Limacina spp. & 11.0 & 50.1 & 65.5 \\
\hline Centropages gracilis & 0.4 & 2.8 & $\mathrm{P}$ & Microsetella rosea & 7.6 & 8.7 & 8.5 & SIPHONOPHORA & & & & Creseis spp. & 0.7 & 6.4 & 3.9 \\
\hline Calanopia spp. & 0.2 & 10.6 & 2.5 & Miracia minor & 0.5 & - & - & Agalma sp. nectophores & 0.4 & - & - & Clio spp. & $\mathrm{P}$ & 0.2 & - \\
\hline Labidocera detruncata & 0.4 & 0.3 & 0.2 & Harpacticoid spp. & - & - & 1.0 & Rosaceae sp. & $\mathrm{P}$ & - & - & Cavolinia spp. & - & - & 2.2 \\
\hline Pontella fera & 0.2 & 0.1 & 0.7 & Corycaeus spp. & 80.0 & 198.4 & 165.6 & Sulculeolaria turgida & $\mathrm{P}$ & 0.1 & - & Atlantid heterop & 0.1 & 0.5 & 1.9 \\
\hline Pontellina plumata & $\mathrm{P}$ & - & $\mathrm{P}$ & Lubbockia squillimana & 0.2 & 0.1 & - & Sulculeolaria chuni & - & $\mathrm{P}$ & - & Lamellibranch larvae & 2.4 & 1.2 & 6.9 \\
\hline Pontellopsis armata & - & - & $\mathrm{P}$ & Oncaea spp. & 60.7 & 272.9 & 168.1 & Diphyes dispar & $\mathrm{P}$ & 0.1 & $\mathrm{P}$ & Squid larvae & - & $\mathrm{P}$ & $\mathrm{P}$ \\
\hline Temora discaudata & $\mathrm{P}$ & 2.5 & 6.0 & Copila mirabilis & 1.2 & 2.2 & 0.8 & Diphyes bojani & - & $\mathrm{P}$ & - & POLYCHAETA & & & \\
\hline Nannocalanus minor & 0.5 & 3.9 & 6.7 & Sapphirina spp. & 0.3 & 1.6 & - & Lensia subtilis & - & - & 1.1 & Sagitella spp. & $\mathrm{P}$ & 1.5 & 0.5 \\
\hline Canthocalanus pauper & 0.5 & 7.9 & 3.2 & Copepod nauplii & 42.5 & 180.7 & 151.7 & Chelophyes contorta & 0.2 & 0.9 & 0.1 & Tomopteris sp & $\mathrm{P}$ & - & - \\
\hline Cosmocalanus darwini & 1.9 & 5.2 & 2.9 & CLADOCERA & & & & Chelophyes appendiculata & $\mathrm{P}$ & - & - & Polychaete larvae & 8.4 & 9.1 & 12.7 \\
\hline Neocalanus gracilis & $\mathrm{P}$ & 0.9 & $\mathrm{P}$ & Evadne spp. & 1.5 & 1.2 & 0.8 & Eudoxoides spiralis & $\mathrm{P}$ & - & - & UROCHORDATA & & & \\
\hline Neocalanus robustior & $\mathrm{P}$ & $\mathrm{P}$ & $\mathrm{P}$ & GIRRIPEDIA & & & & Eudoxoides mitra & - & $\mathrm{P}$ & - & Thalia democratica & $\mathrm{P}$ & $\mathrm{P}$ & - \\
\hline Undinula vulgaris & 0.2 & 2.8 & 13.8 & Cirripede nauplii & 0.5 & - & 2.0 & Abylinae nectophores & 0.6 & 1.6 & 0.5 & Salp imm. & - & 0.2 & - \\
\hline Calocalanus/Mecynocera spp. & 66.7 & 198.9 & 136.1 & Cirripede cyprids & $\mathrm{P}$ & - & $\mathrm{P}$ & HYDROZOA & & & & Doliolids & 1.3 & 3.7 & 2.0 \\
\hline Acrocalanus gibber & 2.3 & - & 21.0 & OSTRACODA & & & & Ceriantharia larvae & - & - & $\mathrm{P}$ & Appendicularia spp. & 93.8 & 142.1 & 154.9 \\
\hline Acrocalanus gracilis & 0.1 & 14.4 & - & Ostracod spp. & 1.0 & 1.9 & 8.8 & Aglaura hemistoma & 3.2 & 1.9 & 0.3 & GHORDATA & & & \\
\hline Acrocalanus monachus & 1.9 & 0.9 & 0.8 & STOMATOPODA & & & & Liriope tetraphylla & $\mathrm{P}$ & $\mathrm{P}$ & - & Fish eggs & $\mathrm{P}$ & $\mathrm{P}$ & 1.3 \\
\hline Paracalanus spp. & 41.8 & 359.0 & 248.2 & Stomatopod larvae & $\mathrm{P}$ & 一 & 2.3 & Solmundella bitentaculata & $\mathrm{P}$ & - & 0.5 & Fish larvae & 0.1 & 0.2 & 1.4 \\
\hline Pareucalanus attenиatus & $\mathrm{P}$ & 0.1 & $\mathrm{P}$ & MYSIDACEA & & & & Leptomedusae spp. & $\mathrm{P}$ & - & - & Myctophid sp. & - & $\mathrm{P}$ & - \\
\hline Rhincalanus rostifrons & $\mathrm{P}$ & 0.1 & 0.9 & Mysid spp. & $\mathrm{P}$ & $\mathrm{P}$ & $\mathrm{P}$ & GTENOPHORA & & & & Branchiostoma sp & - & $\mathrm{P}$ & 0.1 \\
\hline Subeucalanus mucronatus & $\mathrm{P}$ & 4.2 & 0.1 & AMPHIPODA & & & & Ctenophore sp. & - & $\mathrm{P}$ & $\mathrm{P}$ & FORAMINIFERA & & & \\
\hline Subeucalanus pileatus & 0.4 & - & $\mathrm{P}$ & Amphipod spp. & 0.5 & 0.9 & 1.2 & PLATYHELMINTHES & & & & Globigerina spp. & 10.5 & 36.0 & 42.7 \\
\hline
\end{tabular}

imm, immature; MP, Mascarene Plateau; NU, north-bound upwelling; OL, oligotrophic; P, presence <0.05 m³; PL, post larval; sp, single unidentified species; spp, several unidentified species. 
Table 4. Canonical discriminant functions, standardized by within species variance and listed in order of decreasing species abundance.

\begin{tabular}{lrr}
\hline Species & Factor 1 & Factor 2 \\
\hline Oncaea spp. & 2.067 & 0.061 \\
Corycaeus spp. & -1.131 & 0.818 \\
Appendicularia & -1.226 & -0.700 \\
Chaetognatha & -0.685 & 1.360 \\
Microsetella spp. & 1.899 & 0.826 \\
Limacina spp. & 0.783 & -0.205 \\
Globigerina spp. & 1.566 & 0.415 \\
Prosobranch gastropod larvae & -0.634 & 1.551 \\
Polychaete larvae & 1.725 & -0.814 \\
Echinoderm larvae & -1.758 & -0.621 \\
Bryozoan cyphonautes larvae & -1.155 & -0.378 \\
Acrocalanus spp. & -1.185 & -1.358 \\
Euphausiacea (>calyptopis) & -1.098 & 0.357 \\
Lamellibranch larvae & -0.783 & -0.543 \\
Siphonophora & 0.522 & -0.607 \\
Candacia spp. & 0.716 & -0.632 \\
\hline
\end{tabular}

Table 5. (A) Classification matrix (cases in row categories classified into columns). Zoogeographic regions abbreviated as in Table 2. (B) Jackknifed classification matrix.

\begin{tabular}{lrrrc}
\hline A & OL & MP & NU & \% correct \\
\hline OL & 11 & 0 & 0 & 100 \\
MP & 0 & 16 & 0 & 100 \\
NU & 0 & 0 & 8 & 100 \\
Total & 11 & 16 & 8 & 100 \\
\hline B & OL & MP & NU & $\%$ correct \\
\hline OL & 10 & 1 & 0 & 91 \\
MP & 0 & 16 & 0 & 100 \\
NU & 0 & 0 & 8 & 100 \\
Total & 10 & 17 & 8 & 97 \\
\hline
\end{tabular}

analysis for all stations, plotted in the space defined by factors 1 and 2. This confirms the grouping and demonstrates the separation between groups in the multidimensional space defined by the two factors.

\section{Interpretation of species variability}

When regional differences in the abundance of the 16 species/groups listed in Table 4 are examined, differences are found, indicating why they should separate statistically into different biological regimes. The mean number $\mathrm{m}^{3}$ of each individual species/group, occurring in each of the three regions, is invariably lowest in the $\mathrm{OL}$ region. In the NU and MP regions, relative abundance of individual species/groups shows more inter-regional variability. The copepods Candacia spp., Acrocalanus spp., Microsetella spp., Corycaeus spp. and Oncea spp., Euphausiacea, bryozoan larvae and Chaetognatha were more abundant in the NU region and the remaining groups in the MP region.

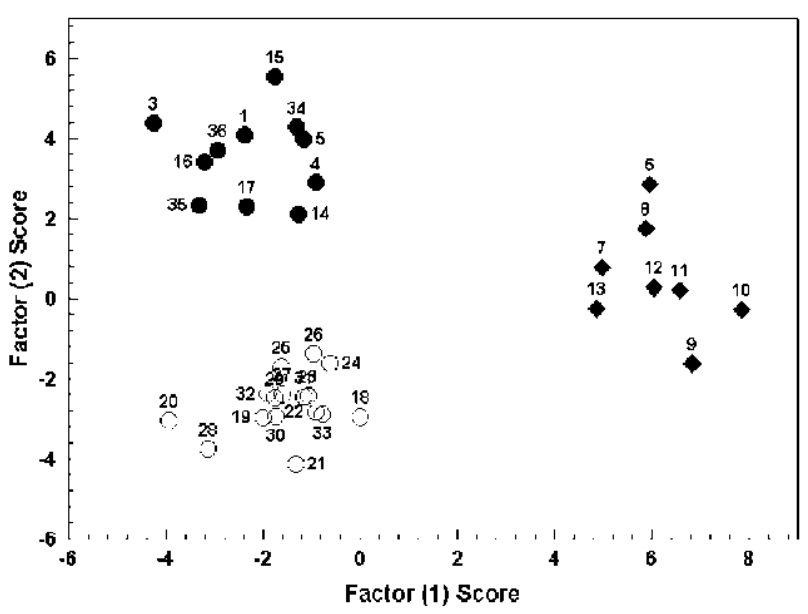

Figure 3. Plot of canonical factor scores for each station from discriminant function analysis.

As a percentage of total organisms in each of the three regions, Corycaeus spp., Siphonophora, echinoderm larvae, polychaete larvae and Appendicularia formed a higher percentage in the OL region, Oncaea spp. and bryozoan larvae in the NU region and Euphausiacea, Chaetognatha, gastropod larvae, Limacina spp. and Globigerina spp. in the MP region.

\section{DISCUSSION}

The discriminant function analysis indicates that the study area can be divided into three taxonomically separable, non-overlapping regions, using linear weighted combinations (factors) of the abundance data for the 16 taxonomic groups. This tends to confirm the hypothesis that the samples come from regions that are measurably different in terms of their community structure.

The biomass data in Figure 2A are interesting, in that the north-bound transect passes through what is essentially part of a sub-tropical, oligotrophic basin. Typical surface biomass values to be expected for such an area might be up to $50 \mathrm{mg} \mathrm{m}^{-3}$ (e.g. Raymont, 1983). A five year survey of the Atlantic Ocean along the Atlantic Meridional Transect (AMT; Robins \& Aiken, 1996; Aiken \& Bale, 2000) sampled the corresponding western part of the South Atlantic, between 4 and $20^{\circ} \mathrm{S}$, in April/ May of five consecutive years (Gallienne \& Robins, 1998). The average surface mixed layer biomass for the AMT series was $39 \mathrm{mg} \mathrm{m}^{-3}$. Less than $8 \%$ of values were above $100 \mathrm{mg} \mathrm{m}^{-3}$. Far from being oligotrophic, the values for the Mascarene north-bound leg are only matched in the 5-y AMT time series over the whole Atlantic, including the upwelling off West Africa, in the area of the confluence of the Brazil and Falkland currents, where the mean biomass was $426 \mathrm{mg} \mathrm{m}^{-3}$ (maximum $673 \mathrm{mg} \mathrm{m}^{-3}$ ). This confluence is a high-energy environment, with very strong physical mixing and upwelling, associated with the confluence of the warm tropical and cold sub-Antarctic currents.

The AMT series also yielded a five-year mean for European continental shelf surface biomass during spring, of $241 \mathrm{mg} \mathrm{m}^{-3}$, with a range of $23-872 \mathrm{mg} \mathrm{m}^{3}$. The data in Figure 2B for the Mascarene south-bound leg (mean biomass $208 \mathrm{mg} \mathrm{m}^{-3}$, range $42-370 \mathrm{mg} \mathrm{m}^{3}$ ), 
are therefore comparable to typical North Atlantic shelf seas in spring.

The correlation between OPG biovolume and TOPEX/ Poseidon, SSHA and SST, may be an important pointer to the physical processes driving mesozooplankton variability in this area. The SSHA and SST are proxies for the physical processes resulting from the interaction of the banks and the South Equatorial current. This relationship indicates a possible causal link between these physical processes and the variability and high levels of mesozooplankton biomass in this area. The latitudinal ranges of the two maxima in Figure 2A, correspond approximately to the two gaps in the ridge either side of the Saya de Malha Bank. Given the lack of physical and biotic supporting data, it is only possible to speculate that this enhancement of mesozooplankton biomass and variability in community structure may be driven by upwelling of nutrients and enhanced primary production, due to turbulence or divergence created by the presence of the ridge in the flow of the South Equatorial Current (Ragoonaden et al., 1987; Sarma et al., 1990). The data from the satellite remote sensing, particularly the SSHA, indicate support for this hypothesis, and the distribution of biomass and variability in community structure between our three regions seem to confirm this relationship.

There may be another source of upwelling of nutrientrich water in this area. Schott \& McCreary (2001) ask the question 'is there an open-ocean upwelling at $5-10^{\circ} \mathrm{S}$ (in the central and western Indian Ocean)'. They show that Ekman divergence along the northern edge of the South Equatorial Current, leads to doming in southern winter between $5-15^{\circ} \mathrm{S}$ and $45-70^{\circ} \mathrm{E}$, and suggest that this is strong enough at times to lead to upwelling of sub-surface waters into the mixed layer. The extension, well to the east of the ridge, of the enhanced chlorophyll levels visible in SeaWiFS imagery during southern winter (Murtugudde et al., 1999; Schott et al., 2002), appears to support this.

Many of the zooplankton species/groups sampled are widely distributed in the surface waters of the Indian Ocean, but a combination of their relative abundance and absence from some samples indicates why the three regions separate statistically. Zooplankton samples from tropical oligotrophic waters typically have a wide species diversity and low numbers of organisms, as was observed in the OL region. A high proportion of siphonophores and non-calanoid copepods is also typical. The NU region was typical of an upwelling area, with the highest number of organisms of the three regions, wide species diversity and evidence of deeper dwelling species. The MP region had numbers of organisms intermediate between the other two regions. It also had higher numbers of benthic invertebrate larvae than the NU region, demonstrating the presence of a shallow water benthic community.

Coastal upwelling systems around the world tend to be episodic, and upwelling events typically last $2-5$ days, so that blooms are dominated by rapidly growing diatoms. Slower-growing zooplankton have no time to respond, leading to decoupling between primary and secondary production and the development of blooms, promoting export production (Abbot \& Barksdale, 1995). Open ocean upwelling systems are driven by physical processes of seasonal duration, often dominated by smaller phytoplankton species, tightly coupled to smaller zooplankton grazers, whose turnover rates are faster than the period of physical disturbance. Grazing prevents the development of blooms, and most of the enhanced production is recycled (Brink et al., 1995). Upwelling in the area of the present study is likely to fall into the second category. It is driven by the South Equatorial Current, and satellite remote sensing of ocean colour indicates that it is seasonal, being strongest in the winter months May-October. Phytoplankton levels, although above the background levels of surrounding open ocean waters, are low (typically 0.3-0.5 $\mathrm{mg} \mathrm{chl} \mathrm{m}^{-3}$ ). Mesozooplankton biomass is high, export production is likely to be low and food availability is likely to encourage the development of higher trophic levels and a pelagic fishery.

If these data are typical of the whole basin downstream of the ridge, where enhanced chlorophyll is evident in remotely-sensed ocean colour imagery, it is possible that an area of the sub-tropical south-western Indian Ocean, whose extent approaches or exceeds $1,000,000 \mathrm{~km}^{2}$, exhibits levels of biological productivity comparable to other upwelling areas of the world's oceans. The extent of many of these areas is relatively small, but they are very important for the fisheries they support and in terms of global biogeochemical fluxes. Open ocean and coastal upwelling areas account for $80-90 \%$ of the world new production (Brink et al., 1995) and 50\% of the world fish catch comes from areas of coastal upwelling (Summerhayes et al., 1995). Given the uncertainty, the remarkable levels of mesozooplankton biomass found in the Mascarene Basin, and the extreme paucity of comparable data for this region, we believe that this region merits further, more detailed study, both in terms of the apparent enhanced biological productivity, and of the physical processes driving it.

The authors would like to thank all members of the Shoals of Capricorn Programme of the Royal Geographical Society (with the Institute of British Geographers) and the Royal Society, who were based at their London headquarters and in the Seychelles and Mauritius, for their help in organizing and supporting this work, especially Mrs Juliet Burnett. We also thank Deon and Charles Erasmus, masters of SRV 'Zuza', for the friendly and professional way in which they helped us in our work aboard their superb vessel. We thank the Seychelles Marine Parks Authority, the Seychelles Coastguard and the Mauritius Institute of Oceanography for their cooperation in the Seychelles and Mauritius respectively. Finally, we thank David Robins for support of this work from the Department of Environment, Transport and Regions, Darwin Initiative research programme 'Biodiversity in the basement of the food web'.

\section{REFERENCES}

Abbott, M.R. \& Barksdale, B., 1995. Variability in upwelled systems as observed by satellite remote sensing. In Upwelling in the ocean (ed. C.P. Summerhayes et al.), pp. 221-238. Chichester: John Wiley \& Sons.

Aiken, J. \& Bale, A.J., 2000. An introduction to the Atlantic Meridional Transect (AMT) Programme. Progress in Oceanography, 45, 251-256.

Bonneville, A., Von Herzen, R.P. \& Lucazeau, F., 1997. Heat flow over Reunion hot spot track: additional evidence for thermal rejuvenation of oceanic lithosphere. Fournal of Geophysical Research-Solid Earth, 102, 22,731-22,747. 
Brink, K.H. et al., 1995. How do coastal upwelling systems operate as integrated physical, chemical and biological systems and influence the geological record? The role of physical processes in defining the spatial structures of biological and chemical variables. In Upwelling in the ocean (ed. C.P. Summerhayes et al.), pp. 103-124. Chichester: John Wiley \& Sons.

Burnett, J.C., Kavanagh, J.S. \& Spencer, T., 2001. Marine science, training and education in the western Indian Ocean: Shoals of Capricorn Programme Field Report 1998-2001. London: Royal Geographical Society (with the Institute of British Geographers).

Field, J.G., Clarke, K.R. \& Warwick, R.M., 1982. A practical strategy for analysing multispecies distribution patterns. Marine Ecology Progress Series, 8, 37-52.

Gabriel, M., Marshall, S. \& Jennings, S., 2000. The Seychelles. In Seas at the millennium: an environmental evaluation, vol. 2 (ed. C.R.C. Sheppard), pp. 233-241. Amsterdam: Pergamon.

Gallienne, C.P. \& Robins, D.B., 1998. Trans-oceanic characterization of zooplankton community size structure using an optical plankton counter. Fisheries Oceanography, 7, 147-158.

Gallienne, G.P. \& Robins, D.B., 2001. Is Oithona the most important copepod in the world's oceans? Fournal of Plankton Research, 23, 1191-1216.

Gallienne, C.P., Robins D.B. \& Woodd-Walker, R.S., 2001. Abundance, distribution and size structure of zooplankton along a $20^{\circ}$ west meridional transect of the northeast Atlantic Ocean in July. Deep-Sea Research II, 48, 925-949.

Herman, A.W., 1992. Design and calibration of a new optical plankton counter capable of sizing small zooplankton. Deep Sea Research, 39, 395-415.

Mackas, D.L., Denman, K.L. \& Abbott, M.R., 1985. Plankton patchiness: biology in the physical vernacular. Bulletin of Marine Science, 37, 652-674.

Manly, B.F.J., 1994. Multivariate statistical methods, 2nd edn. London: Chapman \& Hall.

Murtugudde, R., Signorini, S., Christian, J., Busalacchi, A., McClain, C. \& Picaut, J., 1999. Ocean color variability of the tropical Indo-Pacific basin observed by SeaWiFS during 1997-98. Fournal of Geophysical Research, 104, 18,351-18,366.
Piontkowski, S.A., Williams, R. \& Melnik, T.A., 1995. Spatial heterogeneity, biomass and size structure of plankton of the Indian Ocean: some general trends. Marine Ecology Progress Series, 117, 219-227.

Rao, T.S.S. \& Griffiths, C., 1998. Understanding the Indian Ocean. Perspectives on oceanography. Paris: UNESCO.

Ragoonaden, S., Ramesh Babu, V. \& Sastry, J.S., 1987. Physicochemical characteristics and circulation of waters in the Mauritius-Seychelles ridge zone, Southwest Indian Ocean. Indian Journal of Marine Sciences, 16, 184-191.

Raymont, J.E.G., 1983. Plankton and productivity in the oceans. Oxford: Pergamon Press.

Robins, D.B. \& Aiken, J., 1996. The Atlantic Meridional Transect: an oceanographic research programme to investigate physical, chemical, biological and optical variables of the Atlantic Ocean. Underwater Technology, 21, 8-14.

Sarma, Y.V.B., Gopala Krishna, V.V., Rao, D.P. \& Sastry, J.S., 1990. Thermohaline circulation and water characteristics around Mauritius group of islands. Indian Fournal of Marine Sciences, 19, 196-200.

Schott, F.A., Dengler, M. \& Schoenfeldt, R., 2002. The shallow overturning circulation of the Indian Ocean. Progress in Oceanography, 53, 57-103.

Schott, F.A. \& McCreary, J.P., 2001. The monsoon circulation of the Indian Ocean. Progress in Oceanography, 51, 1-123.

Sokal, R.R. \& Rohlf, F.J., 1995. Biometry. New York: W.H. Freeman.

Summerhayes, G.P., Emeis, K.-C., Angel, M.V., Smith, R.A. \& Zeitschel, B., 1995. Upwelling in the ocean: modern processes and ancient records. In Upwelling in the ocean (ed. C.P. Summerhayes et al.), pp. 1-38. Chichester: John Wiley \& Sons.

Wilkinson, L., Blank, G. \& Gruber, C., 1996. Desktop data analysis with SYSTAT. New Jersey: Prentice Hall.

Submitted 8 January 2003. Accepted $\bullet \bullet \bullet$ 